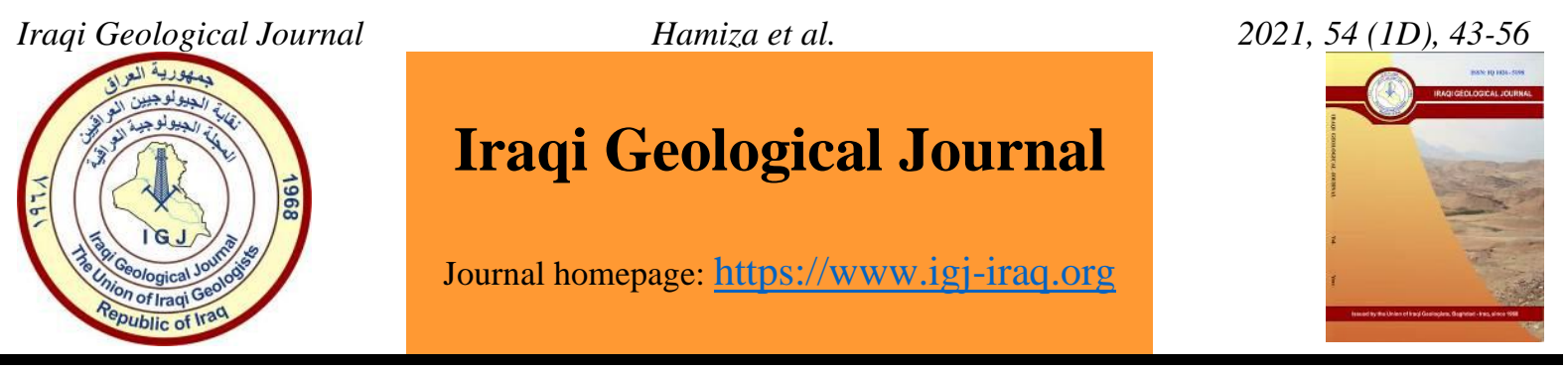

\title{
Evaluation of Air Pollution Dispersion in Al-Daura Refinery After Used Desulfurization Techniques
}

\author{
Ahmed Hamiza ${ }^{1, *}$, Ahmed F. Hassoon ${ }^{2}$ and Ramiz M. Shubbar ${ }^{3}$ \\ ${ }^{1,2}$ Department of Atmospheric Sciences, College of Science, Mustansiriyah University \\ ${ }^{3}$ Department of Automation and Control System, Daura Refinery, Midland Refineries Company \\ *Correspondence: fattah79.atmsc@uomustansiriyah.edu.iq
}

Received:13 August 2020; Accepted: 28 January 2021; Published: 30 April 2021

\begin{abstract}
Sulfur dioxide is one of the dangerous pollutant gases; it has many effects associated with longer exposures to respiratory illness, alterations in the lungs, cardiovascular disease, and premature death. In this study desulfurization techniques are applied to the burned fuel oil used in the Al-Daura refinery at two seasons (January represents winter and July represents summer) to reduce the emission of $\mathrm{SO}_{2}$. Method for desulfurization is based on oxidation (hydrogen peroxide) and solvent extraction techniques by N-methyl-2 -pyrrolidone (NMP) applied on crude fuel oil used in refinery, this method can remove about $75 \%$ of sulfur from fuel oil used to a supplied refinery in 2017. The total amount of burned fuel oil is 60011.6 and $40418 \mathrm{~kg} /$ hour (January-July) through 2017. The emission rate for $\mathrm{SO}_{2}$ is calculated before and after desulfurization suggested to apply and leads to reduce the average monthly rates from 6000 to 2100 and $2900-700 \mu \mathrm{g} / \mathrm{m}^{3}$ at January-July at a distance of $1000 \mathrm{~m}$ from refinery point center. More reduction in farther distances in $\mathrm{SO}_{2}$ concentration reach to more than $35 \%$ resulted after applied desulfurization. This change in emission rate leads to modify the pollution spatial distribution of $\mathrm{SO}_{2}$ concentration according to the Gaussian model for the dispersion of pollutant around the refinery and with a distance reached to more than $10 \mathrm{~km}$. Overall there is a significant change in the air quality of $\mathrm{SO}_{2}$ around Al-Daura refinery specifically in the southeast direction when this technique is applied.
\end{abstract}

Keywords: $\mathrm{SO}_{2}$ concentration; Stability; Air pollution; Jan. and Jul. months; Emission rate

\section{Introduction}

The urban environment considers one of the causes of air pollution, this resulted from the economic development energy consumption, urban road transport and increasing number of urban populations, thus air pollution is stayed to be the main health hazard all over the world (Rosmeika et al. (2014). The sources of air pollution are different but the most have resulted from fuel combustion, this process responds to the emission gases such as carbon monoxide $\mathrm{CO}$, the oxides of sulfur, where $\mathrm{SO}_{2}$ and $\mathrm{SO}_{3}$ (represent as $\mathrm{SO}_{\mathrm{X}}$ ), oxides of nitrogen $\mathrm{NO}$ and $\mathrm{NO}_{2}\left(\mathrm{NO}_{\mathrm{X}}\right)$, and particulates, involving primarily of very fine soot and ash particles, (Cretu et al. (2010). Hydrogen sulfide $\mathrm{H}_{2} \mathrm{~S}$ emissions from burning are negligible in comparison with sulfur oxides $\left(\mathrm{SO}_{\mathrm{X}}\right)$, although the two gases consider the main gas sources of sulfur, constructed for air pollution gases. Sulfur dioxide configures the most rate of sulfur oxides, sulfur dioxide $\mathrm{SO}_{2}$ react in the atmosphere to sulfates this is constructed about $95 \%$ of the oxides of sulfur. In the atmosphere, however, $\mathrm{SO}_{2}$ is a predecessor of highly damaging sulfates $\left(\mathrm{SO}_{4}^{-2}\right)$, made by the chemical addition of oxygen $\left(\mathrm{O}_{2}\right) . \mathrm{SO}_{3}$ is not a stable composite and may react with water $\left(\mathrm{H}_{2} \mathrm{O}\right)$

DOI: $\underline{10.46717 / i g j .54 .1 D .4 M s-2021-04-24}$ 
to form sulfuric acid $\left(\mathrm{H}_{2} \mathrm{SO}_{4}\right)$. SOx in the atmosphere has been acknowledged as a major air pollution problem. $\mathrm{SO}_{2}$ productions cause acid rain, disturb public health, decay materials, and limit visibility (Mudakavi, 2010). Reduce sulfur levels in fuel to a small amount must protect the environment against contamination. Removal of sulfur can be done industrially via hydrodesulfurization (HDS) and by hydrodenitrogenation (HDN) (Shiraishi, 2002). Desulfurization is very important in the subject concerning the clean air and in the regulation of sulfur in fuel, the sulfur problem becoming more serious in general particularly for middle to heavy fuels, because there is large emission of a sulfur component when burning. Most chemistries of fuel processes concentrated on how to produce clean fuels in a more efficient and environmentally friendly fashion (Ali et al., 2009). Many authors used desulfurization techniques, for example, Jedrusik (1998) used two stages process which specified level reduction of emission $\mathrm{SO}_{2}$ to $20 \%$ through $80 \%$ (Jedrusik and Kalinowski and Jedrusik, 1998). In this study laboratory method applied to test fuel oil used on Durra refinery is used as a basis to predict pollutants around Durra refinery, if desulfurization is applied on this fuel, also concentrations of $\mathrm{SO}_{2}$ resulted from this process before and after applied these processes is also considered.

\section{Location of the Study area}

Al-Daura Refinery is the main refinery of in Iraq. It's located in the Al-Daura region, about a few kilometers from the city center southeast of the Baghdad province. Al-Daura Refinery categorized by its important location on the banks of Tigris Canal, covers an area of about (205 Hectares) dimensions length $(1620 \mathrm{~m}$ and width of $860 \mathrm{~m})$ surrounded from the north and west by Karada city that considers as the largest cities in Baghdad province, while from the east by the high way, and from the south by the households of the refinery working teams (Fig. 1).

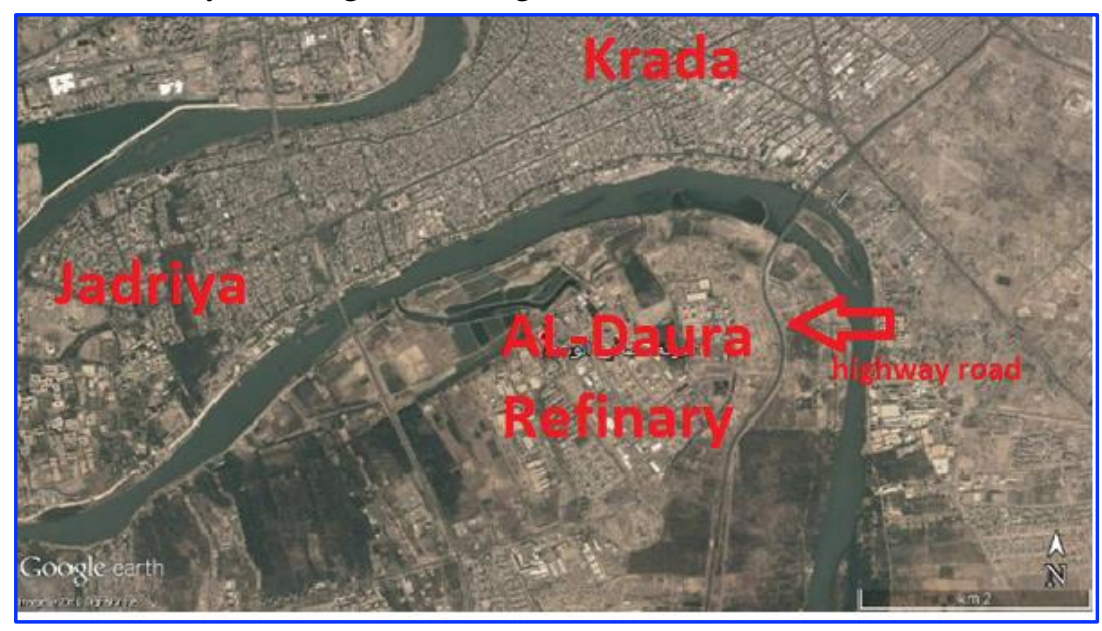

Fig. 1. Location of Al-Daura refinery in Baghdad province

\section{Data}

\subsection{Fuel Used in Refinery}

Al-Daura refinery operates twenty-four a day, and there are large quantities of crude oil processed and the results of production are about 210 thousand barrels per day (Alanbari and Ghanem, 2018). In this study data from reports of the environmental and production units for fuel oil and fuel gas burned inside the refinery at 2017 is taken as a raw data, (Ministry of Oil, 2017). To stat effect of atmospheric conditions on pollution emission only one month from winter season (January), and one from summer season (July) month taken as a sample from all the year months, Table 1 shows the amounts of fuels used at these months, it's taken as volumes per hours or in masses, noted that fuel oil amount at January is greater than July month while the amount of fuel gas is greater in July. Overall these amounts of fuels 
burned in refinery through 30 plants represent 12 units, Table 2 shows the details of these units also the number of the stacks for each unit and its diameters, also stack gas exit temperature, these averages parameters characteristic will be used in calculations later (Shubbar, 2017). Emission from these units will be responsible for pollutant of soil and water in addition to air (Al-Paruany et al., 2016; Ahmad et al., 2016; Al-Adili and Ali, 2005).

Table 1. The fuel oil and fuel gas used in production units in Al-Daura refinery at January and July months (Ministry of Oil, 2017)

\begin{tabular}{lccccc}
\hline Months & Type of fuel & month/ $\mathbf{m}^{\mathbf{3}}$ & hour in month & $\mathbf{~ m}^{\mathbf{3}} / \mathbf{h o u r}$ & Fuel mass in $\mathbf{~ g} / \mathbf{h o u r}$ \\
\hline $\begin{array}{l}\text { January } \\
\text { (winter) }\end{array}$ & Fuel Oil & 46606 & 744 & 62.642608 & 60011.618 \\
& Fuel gas & 6417115 & 744 & 8625.15457 & 12161.4679 \\
July & Fuel Oil & 31436 & 744 & 42.252823 & 40478.204 \\
(summer) & Fuel gas & 9290554 & 744 & 12487.3038 & 17607.0983 \\
\hline
\end{tabular}

\subsection{Atmospheric Parameters Data}

One of the most important matters effected on the dispersion of $\mathrm{SO}_{2}$ concentrations is atmospheric parameter such as wind speed, direction, temperature, cloud cover, relative humidity, atmospheric pressure ...etc. unfortunately observations of these hourly data not available inside the refinery area, thus data used in this study taken from General Organization for Meteorological and Seismic Monitoring and from satellites (GEOS-5) by numerical weather forecast model, the spatial resolution is $0.625^{\circ}$ in latitude and $0.5^{\circ}$ longitude (approximately 50km). Fig. 2. shows the average daily atmospheric parameter for atmospheric pressure, relative humidity and air temperature, respectively. Its notes that there is a great difference in air temperature at Jan. and July $\left(30.5 \mathrm{C}^{0}\right.$ as a monthly average) reflected to wind speed differences (about $1.8 \mathrm{~m} / \mathrm{s}$ ). Relative humidity has opposite behavior for air temperature; thus, January month averages have greater to about $46.5 \%$ from July month.

Table 2. Characteristic of production units in Al-Daura refinery which are used in present study; symbols, stack information (Ministry of Oil, 2017)

\begin{tabular}{|c|c|c|c|c|c|}
\hline Units & Name of operation unit & $\begin{array}{c}\text { Stack's } \\
\text { number }\end{array}$ & $\begin{array}{l}\text { stack } \\
\text { height }\end{array}$ & $\begin{array}{c}\text { Stack } \\
\text { diameter(m) }\end{array}$ & $\begin{array}{c}\text { Stack gas exit } \\
\text { temp.(k) }\end{array}$ \\
\hline 1 & $\begin{array}{l}\text { Crude Distillation } \\
\text { unit_70000 barrel_1 }\end{array}$ & 1 & 21.7 & 2.4 & 640 \\
\hline 2 & $\begin{array}{l}\text { Crude Distillation } \\
\text { unit_70000 barrel_2 }\end{array}$ & 1 & 21.6 & 2.7 & 612 \\
\hline 3 & Catalytic Reformer_1 & 4 & 30 & 1 & 643 \\
\hline 4 & $\begin{array}{c}\text { Kerosene } \\
\text { Hydrogenation }\end{array}$ & 2 & 20 & 1 & 593 \\
\hline 5 & Catalytic Reformer_2 & 5 & 30 & 1.5 & 548 \\
\hline 6 & $\begin{array}{l}\text { Distillation of Crude oil } \\
\text { units_1, and } 3 .\end{array}$ & 3 & 30 & 2 & 573 \\
\hline 7 & $\begin{array}{c}\text { Power unit_1 } \\
\text { (Boiler_1,2,3,4,5,6,7,8) }\end{array}$ & 4 & 30 & 2 & 673 \\
\hline 8 & $\begin{array}{l}\text { Power unit_3 } \\
\text { (Boiler_11\& 12) }\end{array}$ & 1 & 36 & 2.5 & 493 \\
\hline 9 & Lube oil_1 & 3 & 30 & 1 & 573 \\
\hline 10 & Lube oil_2 & 5 & 30 & 1 & 673 \\
\hline 11 & Lube oil_3 & 5 & 30 & 1 & 623 \\
\hline 12 & $\begin{array}{c}\text { Power unit_2 } \\
\text { (Boiler_9\& 10) } \\
\text { Average }\end{array}$ & $\begin{array}{c}1 \\
\text { sum }(35)\end{array}$ & $\begin{array}{c}30 \\
\mathbf{2 8 . 3 m}\end{array}$ & $\begin{array}{c}3 \\
1.76 m\end{array}$ & $\begin{array}{c}673 \\
610(\mathbf{k})\end{array}$ \\
\hline
\end{tabular}


Overall changes in an atmospheric element in January and July will be reflected on stability class, and on wind direction, resulted from differences in atmospheric pressure between two months (Fig. 3). Other important atmospheric elements don't show in Fig. 2, its instantaneous solar radiation and total cloud cover can be used to calculate stability classes by one of stability methods schemes.

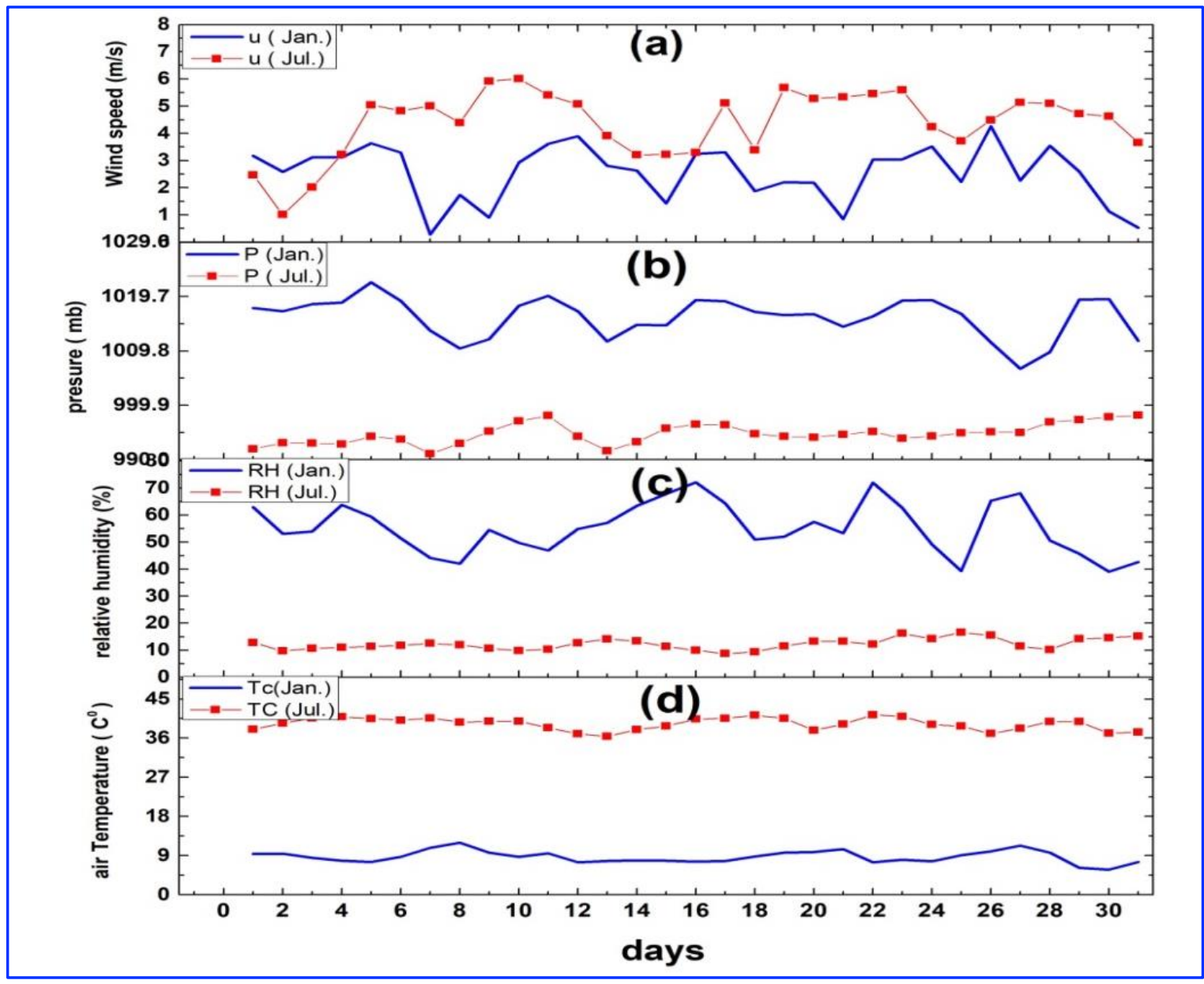

Fig. 2. Average daily recorded atmospheric elements, (a) Wind speed, (b) Atmospheric Pressure (c) Relative humidity, (d) Temp., at January and July month
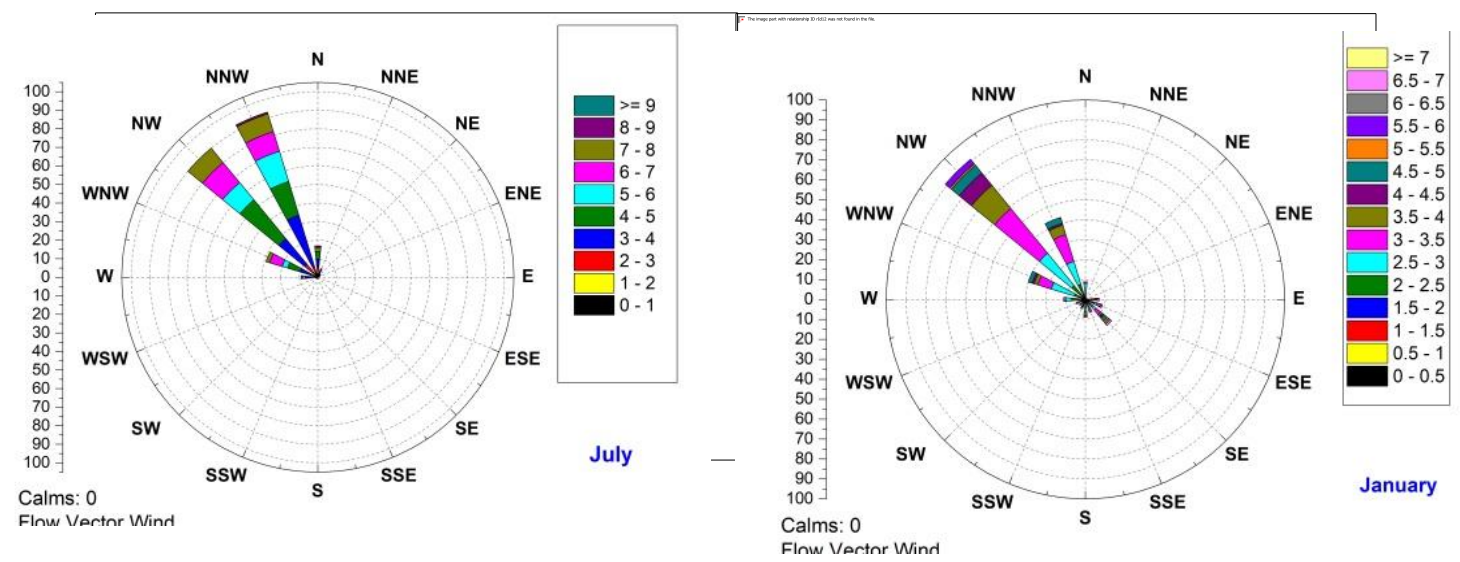

Fig. 3. Wind rose, for hourly wind speed and direction at January and July months 


\section{Methodology}

\subsection{Desulfurization Technique}

Desulfurization is defined as eliminates primarily sulfur and its combinations from solids, liquids, and gases. Predominately, desulfurization encompasses the removal of sulfur oxides from chimney gases, and composites of sulfur in petroleum decontaminating (Wang, 2005). Desulfurization techniques contribute largely to reduce the $\mathrm{SO}_{2}$ emission resulted from refinery products. There are many techniques of desulfurization, such as desulfurization by adsorption, Desulfurization by precipitation (Shiraishi, 2002). Desulfurization via extraction (Ali et al., 2009), Desulfurization by alkylation, (Arias et al., 2008), Desulfurization by selective oxidation (Rostrup-Nielsen and Jens, 2004). But one of a wildly used method (implemented in this study on fuel oil consider in Durra refinery) is hydrodesulfurization (HDS), this method consists of two main processes first oxidation and second extraction as in following steps (Mohammed et al., 2015):

1- Amount of diesel fuel transported to the reactor with the favorite quantity of acetic acid (catalyst).

2- The mixture reached the preferred temperature.

3-Hydrogen peroxide (oxidant) additional to the combination.

4-The mixer moving to set on the prerequisite value.

5-The combination transported to Unravelling funnel.

6- Oxidized diesel fuel disconnected and diverse with a certain quantity of solvent (acetonitrile ACN, N-methyl-2 Pyrrolidone NMP) underneath appropriate moving speed.

7- Later the stirring was motionless, the mixture was permissible to settle and detached. The upper layer was kept and analyzed.

There are four factors that can be varied during an experiment, keeping the others constant (temperature $50^{\circ} \mathrm{C}$, stirring speed $\left.350 \mathrm{rpm}\right)$. These are:

Solvent type (acetonitrile ACN, N-methyl-2 Pyrrolidone NMP)

Solvent/ fuel ratio $(0.5,0.6,0.75$, and 1$)$

Oxidant/ fuel ratio $(0.5,0.75,1$, and 1.5$)$

Catalyst/oxidant ratio $(0.125,0.25,0.5$, and 0.75$)$

These processes simulated on typical fuel oil, where the results exhibit that highest removal of sulfur is $98.5 \%$ using NMP solvent while its $95.8 \%$ for ACN solvent, this follow conditions: stirring speed $350 \mathrm{rpm}$, temperature $50^{\circ} \mathrm{C}$, oxidant/simulated diesel fuel ratio 1 , catalyst/oxidant ratio 0.5 , solvent/simulated diesel fuel ratio 1 . The elimination of sulfur content from the real diesel fuel was more problematic than that from the replicated diesel fuel because many nitrogen, oxygen, and aromatic combinations exist in actual fuel oil, overall, by pragmatic These best conditions upon actual diesel fuel (produced from Al-Daura refinery) with $1000 \mathrm{ppm}$ sulfur content, It was established that sulfur removal is $64.4 \%$ using ACN solvent and about $75 \%$ by means of , N-methyl-2 Pyrrolidone NMP solvent, (this percentage employed as the ratio of sulfur decline in this study to attain emission amount) (Mohammed et al. 2015).

\subsection{Atmospheric Stability Classes}

Atmospheric stability effects on the vertical movement of any aerial parcel, it can be characterized by several methods or parameters depend on the data available. In this study modified Pasqual method is adopted, this method depends on the wind speed record, immediate solar radiation, and total cloud cover over refinery region (Mohan and Siddiqui, 1998) (Table 3). All these bounded conditions assumed in this method to produce hourly class stability data, that used recently to know the concentration of $\mathrm{SO}_{2}$ dispersion according to Gaussian model in area rounded Durra refinery at January and July month 2017. 
Table 3. Stability classes calculations according to modified Pasqual classes (Mohan and Siddiqui, 1998)

\begin{tabular}{|c|c|c|c|c|c|c|c|c|}
\hline \multirow[t]{2}{*}{$\underset{(\mathbf{m} / \mathbf{s})}{\mathbf{U}}$} & \multicolumn{4}{|c|}{$\begin{array}{c}\text { Daytime incoming } \\
\text { Solar Radiation }\left(\mathbf{w} / \mathbf{m}^{2}\right)\end{array}$} & \multirow[t]{2}{*}{$\begin{array}{c}\text { Within1h before } \\
\text { Sunset or after } \\
\text { sunrise }\end{array}$} & \multicolumn{3}{|c|}{$\begin{array}{c}\text { Night cloud } \\
\text { amount (oktas) }\end{array}$} \\
\hline & $\begin{array}{c}\text { Strong } \\
>600\end{array}$ & $\begin{array}{c}\text { Moderate } \\
(300-600)\end{array}$ & $\begin{array}{l}\text { Slight } \\
(<300)\end{array}$ & Overcast & & $0-3$ & $4-7$ & 8 \\
\hline $\mathrm{U} \leq 2$ & A & A-B & B & $\mathrm{C}$ & D & $\mathrm{G}$ & $\mathrm{F}$ & D \\
\hline $2.0-3.0$ & A-B & B & $\mathrm{C}$ & $\mathrm{C}$ & D & E & E-F & D \\
\hline $3.0-5.0$ & B & B-C & $\mathrm{C}$ & C & D & D & D & D \\
\hline $5.0-6.0$ & C & C-D & D & D & D & D & D & D \\
\hline$>6.0$ & $\mathrm{C}$ & D & D & D & D & D & D & D \\
\hline
\end{tabular}

\subsection{Wind Power law}

In the lower portion of the earth's boundary layer represent the surface layer, wind speed growth with aggregate height and has strong slope near the earth. It's often used humble power law of the form (Macdonald, 2003):

$$
\mathrm{u}(\mathrm{z})=\mathrm{U}_{10}\left(\frac{\mathrm{z}}{10}\right)^{\mathrm{p}}
$$

Where:

$\mathrm{u}(\mathrm{z})$ : The wind speed at height is $\mathrm{z}$ in $(\mathrm{m} / \mathrm{s})$ units.

$\mathrm{u}_{10}$ : Wind speed at height $10 \mathrm{~m}$ in $(\mathrm{m} / \mathrm{s})$ units.

The power law quantity p rises with increases surface roughness. For different types of terrain Table 4

Table 4. Wind profile Exponent $\mathrm{p}$ for rough and smooth terrains

\begin{tabular}{lccc}
\hline Stability Class & Description & \multicolumn{2}{c}{ Exponent, p } \\
\hline & & Rough terrain & Smooth terrain \\
A & Very unstable & 0.15 & 0.09 \\
B & Moderately unstable & 0.15 & 0.09 \\
C & Slightly unstable & 0.20 & 0.12 \\
D & Neutral & 0.25 & 0.15 \\
E & Slightly & 0.40 & 0.24 \\
F & Stable & 0.60 & 0.24 \\
\hline
\end{tabular}

\subsection{Dispersion Coefficients}

Dispersion coefficients such as $\sigma_{\mathrm{y}}$ and $\sigma_{\mathrm{z}}$ can be computed from the atmospheric stability class and the downwind distance. Briggs (1973) examines versions of $\sigma_{\mathrm{y}}$ and $\sigma_{\mathrm{z}}$, in urban, rural, and provide an interpolation scheme that agrees with Pasquill-Gifford in the downwind range from $100 \mathrm{~m}$ to $10000 \mathrm{~m}$ (Briggs,1973). Table 5 gives the Briggs sigma. The U.S. EPA recommends these sigma values as the ones most appropriate for dispersion simulations in urban areas (Guideline on air quality models, 1978).

Table 5. The Briggs (1973) sigma functions for urban (Zannetti, 2013)

\begin{tabular}{ccc}
\hline Pasquill stability & $\sigma_{\mathrm{y}}$ & $\sigma_{\mathrm{y}}$ \\
\hline A-B & $0.32 \mathrm{x}(1+0.0004 \mathrm{x})^{-0.5}$ & $0.24 \mathrm{x}(1+0.001 \mathrm{x})^{-0.5}$ \\
C & $0.22 \mathrm{x}(1+0.0004 \mathrm{x})^{-0.5}$ & $0.2 \mathrm{x}$ \\
D & $0.16 \mathrm{x}(1+0.0004 \mathrm{x})^{-0.5}$ & $0.14 \mathrm{x}(1+0.0003 \mathrm{x})^{-0.5}$ \\
E-F & $0.11 \mathrm{x}(1+0.0004 \mathrm{x})^{-0.5}$ & $0.08 \mathrm{x}(1+0.00015 \mathrm{x})^{-0.5}$ \\
\hline
\end{tabular}




\subsection{Effective Stack Height}

If assumed plume dispersed in an open area, the summed stack height and plume height will construct effective stack height $\Delta \mathrm{H} . \Delta \mathrm{H}$ Affected by the number of an element, concerning stack shape, and external concerning the meteorological factor stimulus the rise of the plume. The emission Holding factors are the velocity of the emission at the top of the stack, $\mathrm{v}_{\mathrm{s}}$, the temperature of the emission at the top of the stack $\mathrm{T}_{\mathrm{s}}$, and d diameter of the stack opening. The meteorological factors stimulus plume rise is ambient wind speed $u$, the temperature of the air, $T_{a}$, shear of the wind speed with height $\mathrm{du} / \mathrm{dz}$ and atmospheric stability (Turner, 1994). To calculate plume rise, the buoyancy flux $\mathrm{F}$ requisite first be considered using equation (Haugen, 2015), where:

$\mathrm{F}=$ buoyancy flux $\mathrm{m}^{4} \mathrm{~s}^{-3}$

$$
\mathrm{F}=\frac{\mathrm{g} \mathrm{v}_{\mathrm{s}} \mathrm{d}^{2} \Delta \mathrm{T}}{4 \mathrm{~T}_{\mathrm{s}}}
$$

$\mathrm{g}=$ acceleration of gravity $9.8 \mathrm{~m} / \mathrm{s}^{2}$

$\mathrm{v}_{S}=$ stack gas exist velocity $\mathrm{m} / \mathrm{s}$

$\mathrm{d}=$ top inside stack diameter

After calculate buoyancy flux, effective plume height can estimate according to stability, it's divided to:

\section{1. unstable - neutral buoyant and momentum rise (Turner, 1970)}

In atmospheric conditions of unstable, the values resulted from equation 1, responsible for equation used in calculated $\Delta \mathrm{h}$. For buoyancy flux less than 55

$u_{s}=$ wind speed at stack top

$$
\Delta \mathrm{h}=21.425 \frac{\mathrm{F}^{\frac{3}{4}}}{\mathrm{u}_{\mathrm{h}}}
$$

For F greater or equal to 55:

$$
\Delta h=38.71 \frac{F^{3 / 5}}{u_{h}}
$$

Other effective plume rise equation $\Delta H$ with unstable neutral momentum plume rise is calculated as:

$$
\Delta h=\frac{3 \mathrm{~d} \mathrm{v}_{\mathrm{s}}}{u_{\mathrm{s}}}
$$

\section{Stable buoyancy and momentum rise (Turner, 1970)}

To calculate the final plume, rise for stable condition, stability parameter must be evaluated:

$$
s=\frac{g\left(\frac{d \theta}{d z}\right)}{T}
$$

$\mathrm{g}=$ acceleration of gravity $9.8 \mathrm{~m} / \mathrm{s}^{2}$

$\frac{d \theta}{d z}=$ Change of potential temperature with height $(\mathrm{k} / \mathrm{km})$

$\mathrm{T}=$ ambient air temperature $\mathrm{k}$

$$
\Delta h=\left(\frac{\mathrm{F}}{u_{s} \cdot S}\right)^{1 / 3}
$$

\subsection{Stack Exit Velocity}

Exist velocity depends greatly on the amount of the fuel burned inside the plant unit, where it's one of the important element to calculate buoyancy flux according to equation 2 and effective stack height. This study assumed refinery as one plant unit has one stack (one point), this stack has one average 
height and one average diameter outlet, this assumption is basic to calculate dispersions, Table 6 gives details for values of existing velocity resulted at January and July months (calculated according to Gzar, (1998)). In this table the average temperature of exist gases is $610 \mathrm{k}$, while stack diameter is $1.76 \mathrm{~m}$, this information taken from table 2 .

\section{7. $\mathrm{SO}_{2}$ Emission Rate}

The amount of emission $\mathrm{SO}_{2}$ depends on the rate of fuels burned (liquid or gas), and also on the main rate of sulfur in fuel, for Al-Daura refinery its construct 0.038 and 0.0026 weight rate in fuel oil and fuel gas respectively. This weight rate is very important where its desulfurization techniques employed on it. In this study, Gazer method, (Gzar ,1998) is adopted as a tool to estimated emission rate of $\mathrm{SO}_{2}$. Tables 7 and 8 evaluates emission rate for fuel oil and fuel gas, respectively. The same last steps can apply to fuel gas, where most of the sulfur resulted from $\mathrm{H}_{2} \mathrm{~S}$ in this fuel. If assumed the amount of fuel gas is $\mathrm{X}$ :

$$
\text { Mass of } \mathrm{H}_{2} \mathrm{~S} \text { gas }=\mathrm{X}^{*} \text { (rate molecular weight in fuel gas) }
$$

Fuel oil used in this study assumed sulfur moles is equal to number of the $\mathrm{SO}_{2}$ moles, (Muhsin and Gzar, 1998). Emission rate in Table 7, calculated from equation 8.

Emission Mass of SO2 = (molecular weight of SO2) $*$ ( mole number of SO2 in fuel oil

Table 6. Exist velocity estimated at January and July months for 2017 and for fuel oil and fuel gas

\begin{tabular}{cccccccc}
\hline $\begin{array}{c}\text { Fuels } \\
\text { type }\end{array}$ & Months & $\begin{array}{c}\text { Fuel } \\
\text { amounts } \\
\mathbf{( k g / h )}\end{array}$ & $\begin{array}{c}\text { Rate of } \\
\text { carbon in } \\
\text { fuel Before } \\
\text { and after } \\
\text { burned }\end{array}$ & $\begin{array}{c}\text { Total mass of } \\
\text { gases contain } \\
\text { carbon } \\
\mathbf{( k g )}\end{array}$ & $\begin{array}{c}\text { Average } \\
\text { volume } \\
\text { output gases } \\
\left(\mathbf{m}^{\mathbf{3}}\right)\end{array}$ & $\begin{array}{c}\text { Output } \\
\text { stack cross } \\
\text { section area } \\
\left(\mathbf{m}^{\mathbf{2}}\right)\end{array}$ & $\begin{array}{c}\text { Stack } \\
\text { velocity(m/s) }\end{array}$ \\
\hline \multirow{2}{*}{ Fuel oil } & Jan. & 60011.618 & 19.95 & 1197231.779 & 558.7533108 & 9.6208 & 58.077635 \\
& July & 40478.204 & 19.95 & 807540.1698 & 376.8825313 & 9.6208 & 39.17372062 \\
Fuel gas & Jan. & 12161.5 & 21.055 & 256060.3825 & 120.9452202 & 9.6208 & 12.57122279 \\
Average & July & 17607.1 & 21.055 & 370717.4905 & 175.1013105 & 9.6208 & 18.20028589 \\
\hline
\end{tabular}

Table 7. Emission rate for $\mathrm{SO}_{2}$ from burned fuel Oil at Jan. and July Month 2017

\begin{tabular}{lcccc}
\hline $\begin{array}{l}\text { Months season } \\
\text { represented }\end{array}$ & $\begin{array}{c}\text { Mass of fuel } \\
\text { oil(kg/h) }\end{array}$ & $\begin{array}{c}\text { Mass of sulfur in } \\
\text { fuel oil }\end{array}$ & $\begin{array}{c}\text { Emission of SO} \\
\text { (kg/h) }\end{array}$ & $\begin{array}{c}\text { Emission of SO} \\
\text { (kg/s) }\end{array}$ \\
\hline January & 60011.618 & 2280.441 & 4560.883 & $1,266,912$ \\
July & 40478.204 & 1538.1717 & 3076.345 & $854,539.9$ \\
\hline
\end{tabular}

From interaction equations between $\mathrm{SO}_{2}$ and $\mathrm{H}_{2} \mathrm{~S}$, number of moles for $\mathrm{H}_{2} \mathrm{~S}$ equal to $\mathrm{SO}_{2}$ this will multiplied by molecular weight for $\mathrm{SO}_{2}$ to obtain emission rate of the $\mathrm{SO}_{2}$ (Table 8). Fuels data from Al-Daura refinery are monthly averages, thus the amount of fuel oil and fuel gas divided by 720 hours to get fuel quantity in kg per hours that used to estimate hourly the emission rate ( $\mathrm{kg} / \mathrm{hour}$ ) for $\mathrm{SO}_{2}$ gas, see table 1. From fuels amounts in table 1 , emission rate for $\mathrm{SO}_{2}$ can be evaluated according to Tables 7,8. In Table 8 review emission rate for fuel gas, where the most compound of fuel gas is from $\mathrm{H}_{2} \mathrm{~S}$ the rate of sulfur, in this case, is calculated by multiplying by the rate of fuel amount, a number of $\mathrm{H}_{2} \mathrm{~S}$ moles are equal to the number of mole for $\mathrm{SO}_{2}$. Finally, the number of moles for $\mathrm{SO}_{2}$ is multiplied by molecular weight to calculate the emission rate for $\mathrm{SO}_{2}$ gas in milligram divided by second. Its notes that emission rate of fuel gas have \%09.15 from fuel oil, thus the large rate of pollution in $\mathrm{SO}_{2}$ come from burning of fuel oil, thus all desulfurization technique's will be applied on fuel oil. 
Table 8. Emission rate for $\mathrm{SO}_{2}$ from burned fuel Gas at Jan. and July month 2017

\begin{tabular}{cccccc}
\hline Months & $\begin{array}{c}\text { Mass of fuel } \\
\text { gas }(\mathbf{k g} / \mathbf{h})\end{array}$ & Mass of $\mathbf{H}_{2} \mathbf{S}$ & $\begin{array}{c}\text { Number of } \\
\text { molars }\end{array}$ & $\begin{array}{c}\text { Emission of } \\
\mathbf{S O}_{\mathbf{2}} \mathbf{( k g / h )}\end{array}$ & Emission of SO2 $(\mathbf{m g} / \mathbf{s})$ \\
\hline January & 60011.618 & 2280.441 & 4560.883 & 119.039 & $33,066.47$ \\
July & 40478.204 & 1538.1717 & 3076.345 & 172.34 & $47,872.89$ \\
\hline
\end{tabular}

\subsection{Gaussian Plume Model}

For an uninterrupted point source unconfined at the origin in a uniform (homogeneous) turbulent flow. The clarification to diffusion Equation given by Gaussian plume equation, which is essential of nearly all monitoring dispersion models, see the equation. 10 (Macdonald R., 2003):

$$
C(x, y, z)=\frac{Q}{2 \pi u_{s} \sigma_{y} \sigma_{z}} \exp \left(-\frac{y^{2}}{2{\sigma_{y}}^{2}}\right)\left\{\exp \left(-\frac{(z-\Delta h)^{2}}{2{\sigma_{z}}^{2}}\right)+\exp \left(-\frac{(z+\Delta h)^{2}}{2 \sigma_{z}^{2}}\right)\right\}
$$

Where:

$C=$ point concentration at receptor, in $\left(\mu \mathrm{g} / \mathrm{m}^{3}\right)$.

$(\mathrm{x}, \mathrm{y}, \mathrm{z})=$ ground level coordinates of the receptor relative to the source and wind direction, in meters. $\mathrm{z}=$ height of plume line

$\Delta h=$ operative release height, in meters (m).

$\mathrm{Q}=$ Emission rate, assumed pollutant source located at the origin, in $(\mu \mathrm{g} / \mathrm{s})$.

$\mathrm{u}_{\mathrm{s}}=$ wind speed at stack height, in $(\mathrm{m} / \mathrm{s})$.

$\sigma_{y}$ and $\sigma_{z}=$ standard deviation of plume concentration dispersal in y and z plane, in meters.

\subsection{Model Implemented}

The set of equations from 1 to 10 is modeled by the program, there is a group of steps started from the availability of data by fuel mass used in refinery and atmospheric data, these will be used to calculate parameters needed by Gaussian equation model, but desulfurization techniques applied on fuel by processes explained in the last paragraph, thus emission rate amount will depend on the efficiency of desulfurization processes, the perfect results reflected on $\mathrm{SO}_{2}$ concentration determine with distances from a refinery point source (Fig. 4).

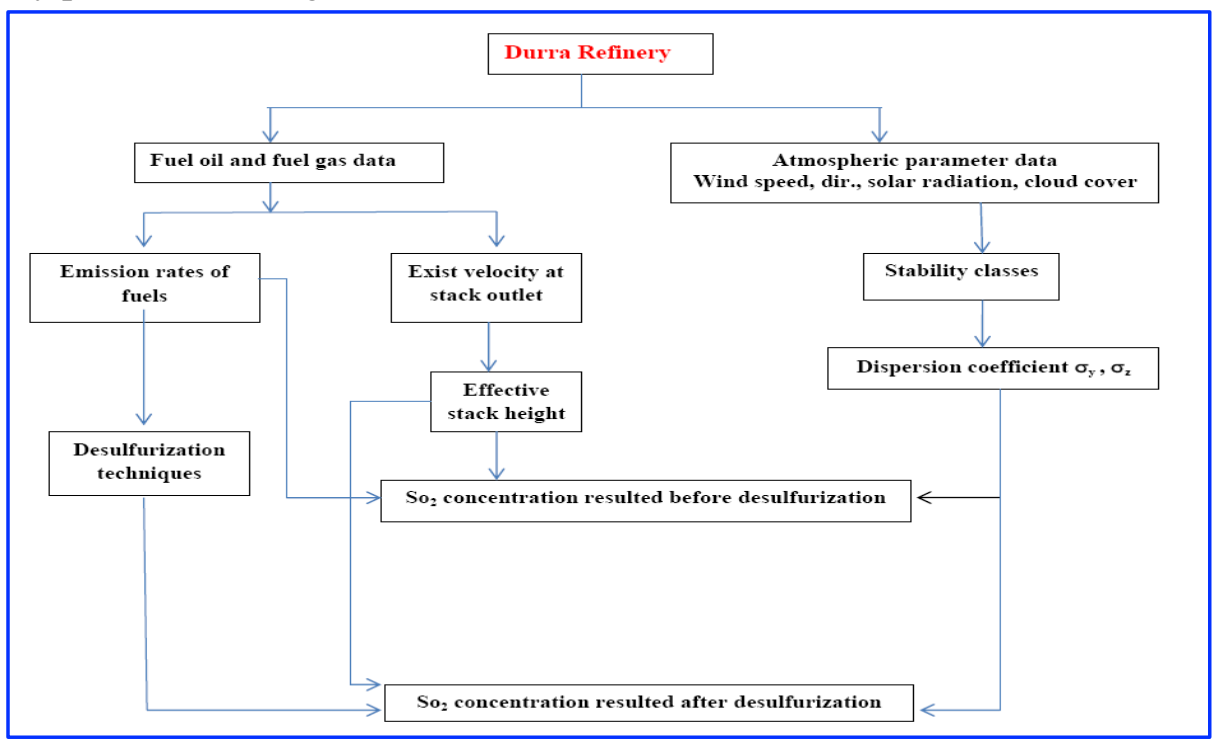

Fig 4. Flow chart shows steps to calculate concentration of $\mathrm{SO}_{2}$ by Gaussian equation model before and after fuel oil desulfurization 


\section{Results and Discussion}

\subsection{Stability Classes}

Stability classes depend greatly on the atmospheric parameter; unfortunately, it's not measured directly inside the refinery area because security procedures. These Atmospheric elements is obtained from satellite and remote sensing (you can review paragraph metrological data in this paper). In this study, the information and conditions in table 3 used to find stability classes. Thus, from hourly data of wind speed at $10 \mathrm{~m}$, total cloud cover and instants short wave solar radiation, stability class resulted, see Fig $5 \mathrm{a}$ for July month and fig $5 \mathrm{~b}$ for January month. From fig $5 \mathrm{a}$, there is a wide distribution of stability classes from A to G. Although this month is very hot its noted that stability class such A, B, A-B have small frequency because activation of wind speed in this month, make most frequency class concentrated on class C about $42 \%$ and class D 39\%, see fig 5a. This situation differs in Jan. month where the large class frequent is $\mathrm{E}$, about $31 \%$, see Fig $5 \mathrm{~b}$. This frequency of stability class very important to determine concentration $\mathrm{SO}_{2}$ pollutant in the refinery.

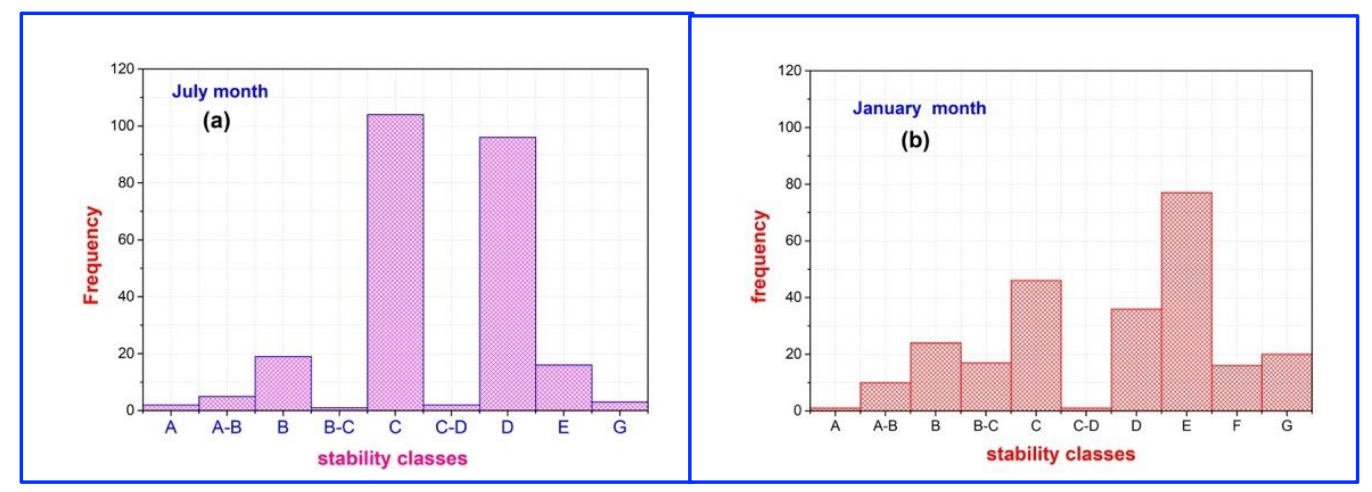

Fig 5. Hourly frequency of stability classes at (a) January month, (b) July month

\subsection{Wind Speed at Stack Height}

Al-Daura located inside or near Baghdad city center, thus to calculate wind speed at stack height output, power law equation considers as urban class according to Table 4. This table implemented hourly stability condition, on other hand, most of the stacks in refinery have a height of about $30 \mathrm{~m}$ as average about $28.3 \mathrm{~m}$ (Fig. 5 and Table 6).. Fig. 6 compares between wind speed at $10 \mathrm{~m}$ and $30 \mathrm{~m}$ calculated at stack outlet, at July and January months. Wind speed at stack height is very important to estimate effective stack height.

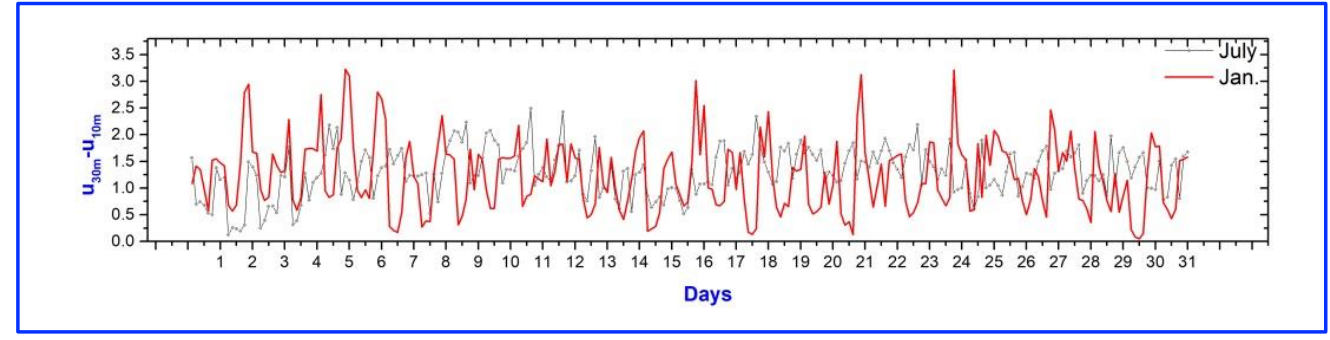

Fig 6. Hourly wind speed difference between $10 \mathrm{~m}$ and at stack height $30 \mathrm{~m}$ according stability class and power law at January and July month

\subsection{Calculates Effective Stack Height}

According to later paragraph equations from 2 to 7 used to calculate hourly effective stack height at January and July months according to stability classes, unstable included classes A, B, C, D and stable classes E, F, G. Average effective height is reached to about 670meter in unstable classes in Jan. month, 
because low wind speed record (Figs. 2 and 3), but this height decreases to more than 30 meter in stable class at January and July months (Fig.6 ).

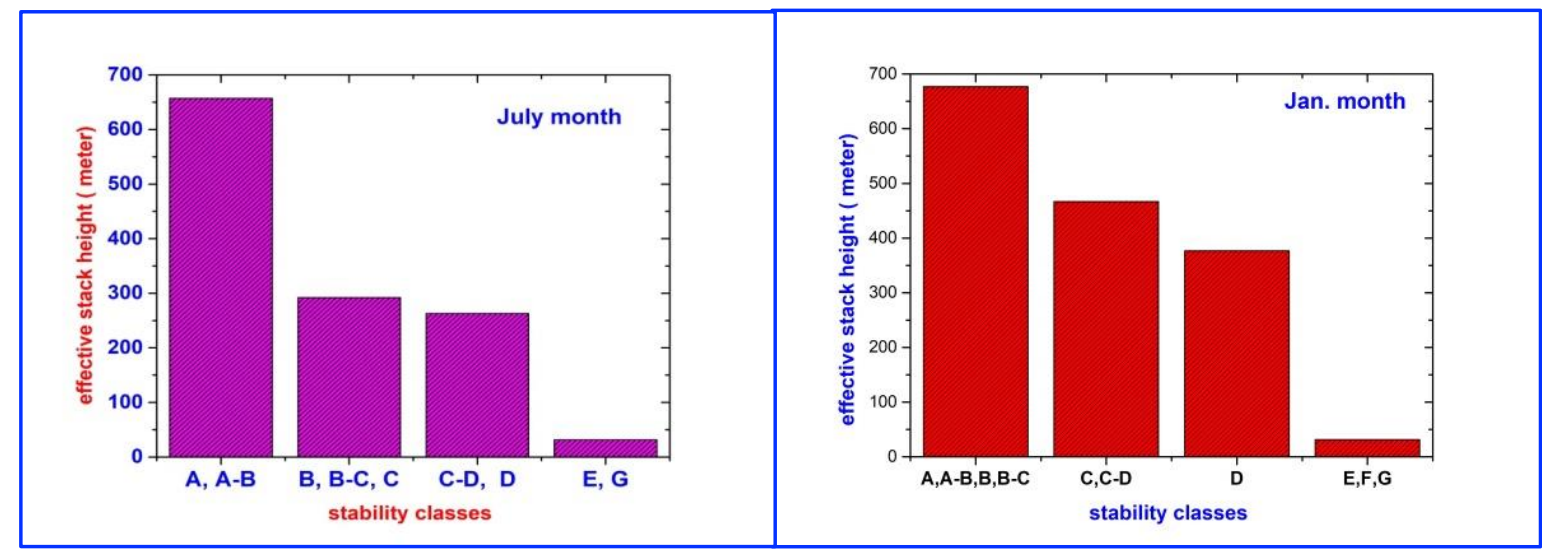

Fig 7. Average effective stack height resulted from stability classes

\section{4. $\mathrm{SO}_{2}$ Concentrations Before Desulfurization}

Gaussian model equation (10) for dispersion of $\mathrm{SO}_{2}$ gas is calculated at a different distance from refinery point area. This equation calculates the hourly concentration of $\mathrm{SO}_{2}$ (every 3 hours) received by ground $(\mathrm{z}=0)$ at a different distance $1000 \mathrm{~m}, 5000 \mathrm{~m} \ldots . .10000 \mathrm{~m}$, also at different domain directions, but this equation needs to calculate vertical and horizontal diffusion coefficients of $\sigma_{\mathrm{y}}$ and $\sigma_{\mathrm{z}}$, from Table 5. Emission rate at January and July month for fuel oil and fuel gas is applied in this model equation according to Tables 6 and 7. From compassion between emissions rate of fuel oil and fuel gas it's $2 \%$ from fuel oil emissions at January month and 5\% at July month, obviously most emission resulted from fuel oil only and concentration of $\mathrm{SO}_{2}$ will be from fuel oil only, and emission from gas oil neglected in this study. On other hand, Resulted show the great effect of stability classes on concentration amount at different time hours, and concentrations at January month is larger than July because a large amount of fuel oil used and large frequent of stable classes also Fig. 8. At 1000m distance around refinery point as a circle radius distance, most $\mathrm{SO}_{2}$ concentration is very high at the range about (680-56000) $\mu \mathrm{g} / \mathrm{m}^{3}$ and (600-16000) $\mu \mathrm{g} / \mathrm{m}^{3}$ for January and July. respectively, the large hour values concentrated at stability class F and G, (Fig. 8). In distance 5000m the concentration is in the range (50$4000)$ and $(35-1000) \mu \mathrm{g} / \mathrm{m}^{3}$ for Jan. and Jul. respectively, while at $10000 \mathrm{~m}$ distance from the refinery concentration reduce to range (19-1500) and (11-450) $\mu \mathrm{g} / \mathrm{m}^{3}$. Overall most concentration of $\mathrm{SO}_{2}$ is over national ambient air quality standard $\left(100 \mu \mathrm{g} / \mathrm{m}^{3}\right)$, even at $10000 \mathrm{~m}$ distance and this depends greatly on stability class domain (Fig. 8).

\section{5. $\mathrm{SO}_{2}$ Concentrations After Desulfurization}

As in flowchart (Fig. 4), last processes is desulfurization applied by method type hydro desulfurization (HDS), see desulfurization paragraph, and according some applied studies (Mohammed et al. 2015 ) Applied on real fuel oil used in Al-Daura refinery sample, where hydro desulfurization (HDS) method reduced sulfur to $75 \%$ by used N-methyl-2 Pyrrolidone NMP as a solvent. This technique applied on fuel oil amount at January and July months, where emission rate of $\mathrm{SO}_{2}$ reduced to $316 \mathrm{~g} / \mathrm{s}$ and $213 \mathrm{~g} / \mathrm{s}$ respectively at Jan. and Jul. from compared the average monthly $\mathrm{SO}_{2}$ concentration before and after desulfurization it's clear that only distance more than $1000 \mathrm{~m}$ will be danger and over the national ambient air quality standard $\left(100 \mu \mathrm{g} / \mathrm{m}^{3}\right)$ (Fig. 9). The most important factor in determining the level of pollutant in any area is domain wind direction at a specified period, this will cause increases in 
pollution levels in the area located north to the north-west of Al-Daura refinery point, bounded by working houses (Fig. 10).

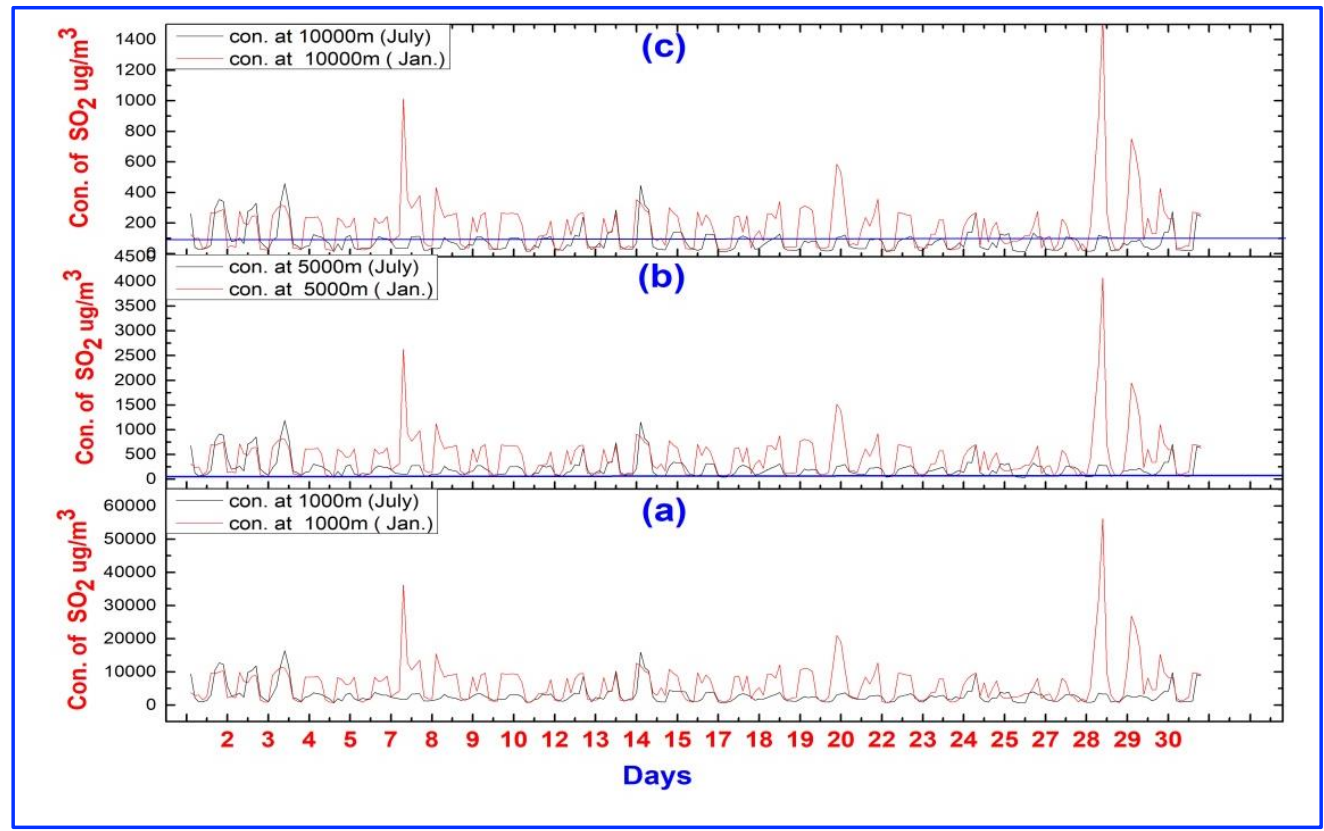

Fig 8. Time series concentration of $\mathrm{SO}_{2}$ with distance according at January and July Months

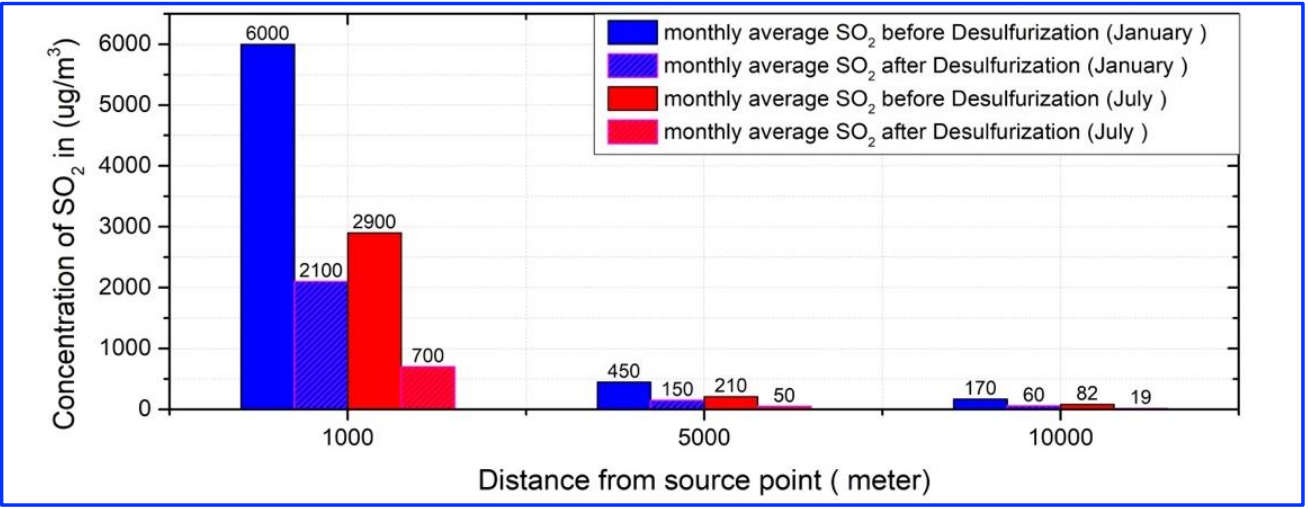

Fig 9. Monthly average $\mathrm{SO}_{2}$ concentration at January and July month before and after desulfurization

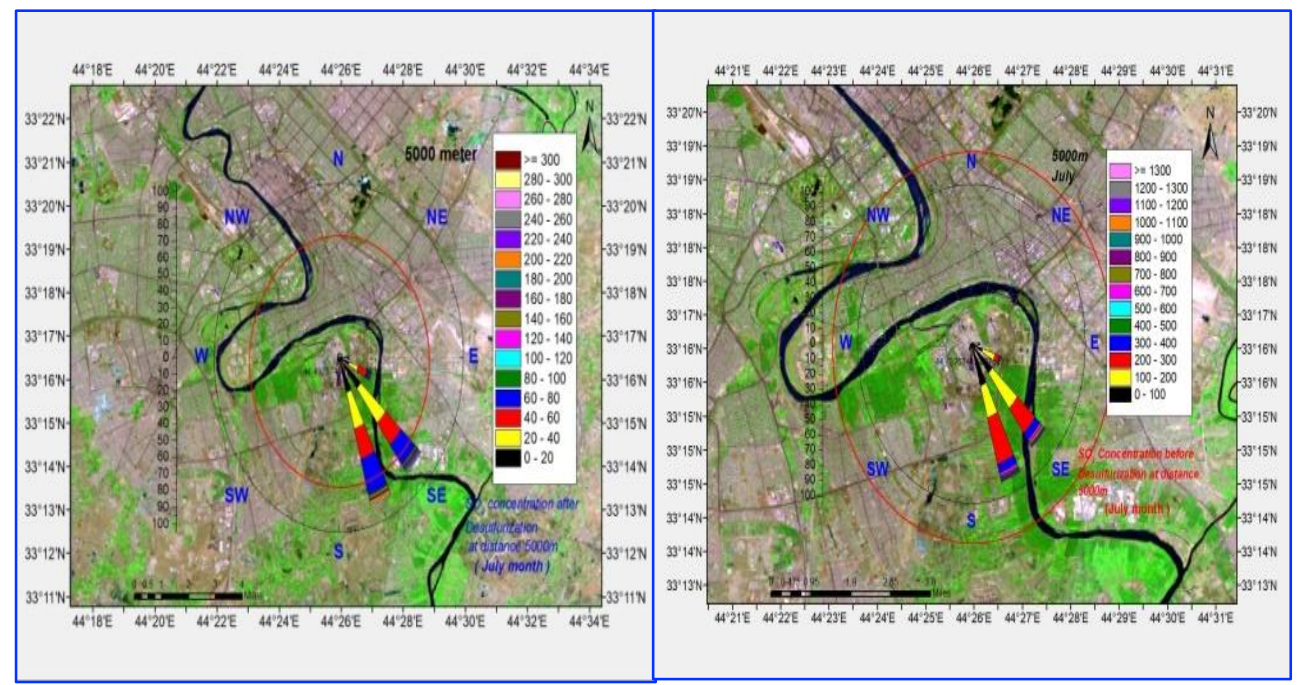

Fig 10. Pollutant wind over refinery before and after desulfurization 


\section{Conclusions}

- Hourly atmospheric parameters from January to July months have a large change in their values at the range for wind speed, atmospheric pressure and air temperature respectively.

- At hours (January-July) month domain wind direction is north-west to north-north-west; this will change the pollutant plume path to the south-east.

- Emission rate resulted from burned fuel oil and fuel gas at (Jan.-July) is 1266 - 33 and 854-47 $\mathrm{g} / \mathrm{s}$ respectively, the emission rate of fuel gas configures about $3 \%$ from fuel oil.

- The most frequent stability class calculated from the modified Pasqual method in class $\mathrm{C}$ in July, and E at January month.

- The highest effective plume height at Jan. larger than July because active horizontal wind speed at this month.

- There is the great concentration level of $\mathrm{SO}_{2}$ at some hour, because domain stability classes $\mathrm{E}$, $\mathrm{F}, \mathrm{G}$, although the large distances from refinery point area about $10000 \mathrm{~m}$, this concentration level overcome the national ambient air quality standard $100 \mu \mathrm{g} / \mathrm{m}^{3}$, this depends on stability class domain.

- The south-east area at (Jan-July) that represent high way and houses of the Refinery staff consider the most area affected by $\mathrm{SO}_{2}$ gas pollutants through this period because in these distance $\mathrm{SO}_{2}$ pollutant in out of national ambient air quality standard according to World Health Organization (WHO).

- There are a large number of desulfurization method, but the method used in this study is hydro desulfurization (HDS) that need two stages, first oxidation and second extraction, this method for desulfurization used in Al-Daura refinery to where extraction is done by solvent N-methylz Pyrrolidane this reduce about $75 \%$ of sulfur from the sample of fuel oil.

- Desulfurization processing can reduce $\mathrm{SO}_{2}$ average concentration to about $35 \%$ and $24 \%$ at January and July months in the distance of $1000 \mathrm{~m}$ from refinery center point.

- Desulfurization techniques if applied will be made the distance $5000 \mathrm{~m}$ from refinery under national ambient air quality standard in July month and sometimes in January month dependent on the stability classes and amount of fuel oil burned at this period.

\section{Acknowledgements}

The authors are very grateful to the Editor in Chief Prof. Dr. Salih M. Awadh, the Secretary of Journal Mr. Samir R. Hijab. and the Technical Editors for their great efforts and valuable comments.

\section{References}

Muhsin, K. K., Gzar, H. A. 2009. Pollutants emission and dispersion from flares: A gaussian case study in Iraq. Journal of Al-Nahrain University, 12(4), 38-57.

Ahmad, A. B., Al-Paruany, K. B., Khudair, K. H., Hashim, M. F.,Naji, H. S., Taha, A. S. 2016. Estimation of the total trihalomethanes concentration in drinking water in some area of Baghdad, Iraq. Iraqi Geological Journal, 39-49(1), 77-78.

Al-Adili, A., Ali, S. 2005. Hydro chemical evolution of shallow ground water system within Baghdad city-Iraq. Iraqi Geological Journal, 34-38(1), 134-139.

Alanbari, M. A, and Ghanem, I. R. 2018. Evaluating and comparing the potential environmental impacts from the production of diesel and liquefied petroleum gas, Al-Daura refinery, Baghdad, Iraq. Journal of Engineering and Sustainable Development, 22(No. 2 (part-6)), 131-140.

Ali, S. H., Hamad, D. M., Albusairi, B. H., Fahim, M. A. 2009. Removal of dibenzothiophenes from fuels by oxydesulfurization. Energy \& fuels, 23(12), 5986-5994.

Al-Paruany, K. B., Fatah, E. H., Abud-Salam, A. 2016. Concentration of nitrate in groundwater wells in Baghdad city, Iraq. Iraqi Geological Journal, 39-49(1), 98-106. 
Arias, M., Laurenti, D., Geantet, C., Vrinat, M., Hideyuki, I., Yoshimura, Y. 2008. Gasoline desulfurization by catalytic alkylation over silica-supported heteropolyacids: from model reaction to real feed conversion. Catalysis Today, 130(1), 190-194.

Briggs, G. A. 1973. Diffusion estimation for small emissions, in environmental research laboratories. National Oceanic and Atmospheric Administration.

Cretu, M., Teleaba, V., Ionescu, S., Ionescu, A. 2010. Pollution scenarios through atmospheric dispersion modelling based on real measurements-impact on human health. WSEAS Transactions on Environment and Development, 6, 604-613.

Gelaro, R., McCarty, W., Suárez, M. J., Todling, R., Molod, A.Takacs, L., Wargan, K. 2017. The Modern-Era retrospective analysis for research and applications, Version 2 (MERRA-2). Journal of Climate, 30, 54195454.

Guideline on air quality models. 1978. U.S. Environmental Protection Agency. North Carolina: Research Triangle Park.

Gzar, H. A. 1998. Mathematical Modeling for Dispersion of Air Pollutants Emitted from Al- Daura Oil Refinery Stacks. M. Sc. Thesis, College of Engineering, University of Baghdad, Baghdad, Iraq.

Haugen, D., 2015. Lectures on air pollution and environmental impact analyses. Springer.

Iraqi general organization for meteorological and seismic monitoring. Retrieved from http://www.meteoseism.gov.iq/.

Macdonald, R., 2003. Theory and objectives of air dispersion modelling (Vol. 1). Waterloo: Modelling Air Emissions for Compliance.

Ministry of Oil, 2017. Department of studies and research of the refinery, burned fuel for all processes of production. baghdad. Retrieved from https://mrc.oil.gov.iq/

Mohammed, W. T., Almilly, R. F., and Al-Ali, S. B., 2015. Desulfurization of diesel fuel by oxidation and solvent extraction. Journal of Engineering, 21(2), 87-102.

Mohan, M., Siddiqui, T. A., 1998. Analysis of various schemes for the estimation of atmospheric stability classification. atmospheric environment, 32(2), 3775-3781.

Mudakavi, J., 2010. Principles and practices of air pollution control and analysis. United States: IK International Pvt Ltd.

Rosmeika, Yuwono, A. S., Wulandani, D. 2014. Case study on air pollutants emissions from boiler stack of biodiesel plant using atmospheric dispersion modelling. Indian Journal of Scientific Research and Technology, 2(3), 11-17.

Rostrup, N., Jens R. 2004. Fuels and energy for the future:the role of catalysis. Catalysis reviews, 46(3-4), 247270.

Shiraishi, Y., Tachibana, K., Hirai, T., Komasawa, I. 2002. Desulfurization and denitrogenation process for light oils based on chemical oxidation followed by liquid liquid extraction. Industrial and Engineering Chemistry Research, 41(17), 4362-4375.

Shubbar, R. M., 2017. Numerical simulation of air pollutants using CALPUFF model at an urban area in BaghdadIraq. Ph. D thesis, Pukyong National University.

Turner, D. 1970. Workbook of Atmospheric Dispersion Estimates. North corolina: Office of Air Programs Publication No. AP-26.

Turner, D., 1994. Workbook of atmospheric dispersion estimates: an introduction to dispersion modeling. (Vol. 2). Florida: CRC press, (Inc library of congrase).

Wang, L. K. 2005. Advanced air noise pollution control (Totowa ed., Vol. Vol. 2.). (N. C.-T. Eds. Lawrence K. Wang, Ed., \& N. Totowa, Trans.) new jersey: Humava press. Retrieved 2005

Zannetti, P. 2013. Air pollution modeling: theories, computational methods and available software. Monrovia, California: Springer Science \& Business Media. 